\title{
VARIASI SUHU PEMADATAN PADA CAMPURAN BETON ASPAL MENGGUNAKAN BAHAN TAMBAH ANTI STRIPPING
}

\author{
Anni Susilowati ${ }^{(1)}$, Eko Wiyono ${ }^{(2)}$ \\ ${ }^{1,2}$ Jurusan Teknik Sipil Politeknik Negeri Jakarta, Jln. Prof. Dr. G. A. Siwabessy, Kampus Baru UI Depok \\ 16425, Telp. 0217863532, email: \\ anni_susilowati@yahoo.co.id,ww_eko@yahoo.co.id,
}

\begin{abstract}
ABSTRAK
Suhu pemadatan merupakan faktor yang sangat penting dalam proses pemadatan karena mempengaruhi tingkat kepadatan campuran beton aspal. Penelitian ini menggunakan bahan aditif Wetfix Be, yang merupakan bahan kimia anti stripping berguna untuk meningkatkan ikatan dan menstabilkan campuran antara agregat dan aspal terutama pada musim hujan. Tujuan penelitian untuk mendapatkan nilai properties Marshall dengan berbagai variasi suhu pemadatan dan menentukan suhu pemadatan yang optimum pada campuran beton aspal dengan menggunakan bahan tambah anti stripping. Variabel bebas pada penelitian ini adalah variasi suhu pemadatan pada pembuatan beton aspal yaitu $70^{\circ} \mathrm{C}, 90^{\circ} \mathrm{C}, 110^{\circ} \mathrm{C}$, $130^{\circ} \mathrm{C}$, dan $150^{\circ} \mathrm{C}$, dengan Kadar Aspal Optimum (KAO) 0,6\%, dan Wetfix Be 0,3\% terhadap kadar aspal optimum. Metode pengujian menggunakan Marshall berdasarkan SNI 06-2489-1991. Hasil penelitian menunjukkan bahwa penambahan suhu pemadatan pada aspal beton dapat meningkatkan nilai kepadatan, \% Rongga Terisi Aspal, Stabilitas, dan Marshall Quotient serta menurunkan \% rongga di antara agregat, $\%$ rongga dalam campuran dan kelelehan. Didapat rentang Suhu pemadatan yang masih memenuhi parameter Marshall pada suhu $120^{\circ} \mathrm{C}$ sampai dengan $160^{\circ} \mathrm{C}$. Adapun nilai suhu optimum pemadatan untuk campuran beton aspal yang sebesar $140^{\circ} \mathrm{C}$, dengan nilai VMA $18,10 \%$, VFB $73,09 \%$, VIM 4,88 \%, Stabilitas 1228,28 kg, kelelehan 3,93 mm dan MQ 362,14 kg/mm, memenuhi spesifikasi Bina Marga 2010.
\end{abstract}

Kata kunci: Anti Stripping, Suhu, Pemadatan, Wetfix Be

\section{ABSTRACT}

Compaction temperature is a very important factor in the compaction process because it affects the density level of asphalt concrete mixtures. This research uses Wetfix Be additive material, which is an anti-stripping chemical which is useful to increase bonding and stabilize the mixture between aggregates and asphalt, especially in rainy seasons. The aim of the study was to obtain Marshall properties with compaction temperature variations and determine the optimum compaction temperature in asphalt concrete mixtures using added anti-stripping materials. The independent variable in this study is the compaction temperature variations in asphalt concrete manufacturing is $70^{\circ} \mathrm{C}, 90^{\circ} \mathrm{C}, 110^{\circ} \mathrm{C}, 130^{\circ} \mathrm{C}$, and $150^{\circ} \mathrm{C}$ with optimum asphalt content $(\mathrm{OAC})$ of $6 \%$, and Wetfix Be of $0.3 \%$ against optimum asphalt content. Testing method using Marshall based on SNI 06-2489-1991. The results showed that the addition of the compaction temperature on concrete asphalt could increase the density value, percentage of the voids filled with asphalt, stability, and Marshall quotient; and reduce the voids in the mineral aggregates, $\%$ voids in the mixture and flow. The compaction temperature range obtained which still meets Marshall Parameters was from $120^{\circ} \mathrm{C}$ to $160^{\circ} \mathrm{C}$. The optimum compaction temperature value for asphalt concrete mixtures were $140{ }^{\circ} \mathrm{C}$, with VMA values of $18.10 \%$, VFB $73.09 \%$, VIM $4.88 \%$, stability of $1228.28 \mathrm{~kg}$, flowing of $3.93 \mathrm{~mm}$ and $M Q$ of 362,14 kg/mm which meet the specifications of Bina Marga 2010.

Keywords: Anti-Stripping, Compaction Temperature, Wetfix Be 


\section{PENDAHULUAN}

Beberapa faktor penyebab kerusakan jalan adalah efek air, kendaraan kelebihan beban, aplikasi konstruksi perkerasan yang tidak memenuhi persyaratan teknis, proses pemadatan campuran beraspal yang dilakukan di lapangan pada temperatur yang tidak tepat dan tidak sesuai dengan yang disyaratkan, sehingga akan mempengaruhi karakteristik campuran beton aspal. Salah satu usaha untuk meningkatkan struktur perkerasan, dapat dilakukan dengan memperbaiki material dan metoda pelaksanaan di lapangan agar sesuai dengan persyaratan uji di laboratorium. Hal ini dikarenakan suhu pemadatan merupakan faktor yang sangat penting dalam proses pemadatan pada campuran beraspal, karena mempengaruhi tingkat kepadatan campuran beton aspal. Proses pemadatan yang menghasilkan tingkat kepadatan yang tidak memenuhi persyaratan akan menyebabkan menurunnya kualitas karakteristik beton aspal seperti stabilitas, durabilitas, fleksibilitas, ketahanan terhadap geser, ketahanan terhadap kelelehan dan kedap air.

Hasil penelitian [1] dengan Kadar Aspal Optimum 6\% dan bahan anti Stripping Wetfix Be 0,3\% dapat meningkatkan nilai VMA, VIM dan Stabilitas Marshall Sisa sebesar $96,90 \%$, sehingga campuran beton aspal ini memiliki ketahanan yang tinggi terhadap kerusakan yang ditimbulkan oleh air.

Suhu pemadatan merupakan faktor yang sangat penting dalam proses pemadatan pada campuran beraspal, karena mempengaruhi tingkat kepadatan campuran beton aspal. Menurut [2] suhu pencampuran beton aspal adalah antara $140^{\circ} \mathrm{C}$ sampai dengan $160^{\circ} \mathrm{C}$. Suhu pemadatan di lapangan merupakan aplikasi dari hasil penelitian suhu pemadatan di laboratorium [3]. Suhu yang digunakan pada proses pemadatan di lapangan sebesar $110^{\circ} \mathrm{C}-160^{\circ} \mathrm{C}$. bahwa Suhu ideal pada proses pemadatan aspal beton didapat pada suhu antara $128^{\circ} \mathrm{C}-150^{\circ} \mathrm{C}$.

Pada saat keluar dari instalasi pencampuran, campuran aspal beton harus mempunyai suhu $135^{\circ} \mathrm{C}$ sampai dengan $170^{\circ} \mathrm{C}$. Adapun suhu pemadatan bekisar antara $90^{\circ} \mathrm{C}$ sampai dengan $110^{\circ} \mathrm{C}$. Temperatur pencampuran adalah pada temperatur viscositas $170+20 \mathrm{cSt}$, sedangkan temperatur pemadatan pada temperatur viscositas $280+30 \mathrm{cSt}$ [2].

Untuk mencapai kepadatan yang optimal maka pemadatan harus mulai pada temperatur yang optimal dengan syarat bahwa tidak boleh timbul retak selama pemadatan awal, setelah dipadatkan temperatur campuran akan menurun tergantung kepada temperatur udara, kecepatan angin dan tebal penghamparan, oleh karena itu maka waktu pemadatan juga harus ditentukan di dalam percobaan [4].

Menurut [3] menggunakan Modifikasi Bitumen Limbah Plastik, didapat hasil bahwa nilai VMA, VIM, dan Flow murni semakin menurun sedangkan Nilai VFA dan Stabilitas meningkat pada aspal modifikasi maupun aspal murni dengan bertambahnya suhu pemadatan dalam campuran. Adapun suhu optimum sebesar $143^{\circ} \mathrm{C}$ dan $148^{\circ} \mathrm{C}$. Menurut [5], menunjukkan bahwa suhu pemadatan sangat mempengaruhi parameter Marshall dan nilai durabilitas campuran beton aspal AC-BC. Suhu pemadatan yang masih memenuhi persyaratan untuk campuran beton aspal $\mathrm{AC}-\mathrm{BC}$ menggunakan aspal Retona Blend 55 adalah pada suhu $130^{\circ} \mathrm{C}$ sampai dengan $150^{\circ} \mathrm{C}$, sedangkan untuk suhu di bawah suhu $130^{\circ} \mathrm{C}$ tidak memenuhi lagi persyaratan. Suhu pemadatan yang terbaik adalah pada suhu $150^{\circ} \mathrm{C}$ yang menghasilkan kinerja campuran yang lebih baik. Adapun 
menurut [6] hasil pengujian Marshall pada suhu $135^{\circ} \mathrm{C}, 145^{\circ} \mathrm{C}$, dan $155^{\circ} \mathrm{C}$ pada batas tengah telah memenuhi semua parameter Marshall. Hanya pada suhu $125^{\circ} \mathrm{C}$ dan $115^{\circ} \mathrm{C}$ yang tidak memenuhi parameter Marshall dikarenakan nilai Void in Mix (VIM) dan nilai Marshall Quotient (MQ) tidak masuk Spesifikasi Bina Marga 2010. Adapun pengujian Marshall batas bawah pada suhu $115^{\circ} \mathrm{C}, 125^{\circ} \mathrm{C}$, dan $135^{\circ} \mathrm{C}$ tidak memenuhi semua parameter Marshall, dikarenakan nilai Marshall Quotient (MQ) tidak masuk Spesifikasi [7].

Tujuan penelitian ini menganalisis Variasi Suhu Pemadatan Campuran Beton Aspal Menggunakan Bahan Tambah Anti Stripping, dengan target hasil penelitian suhu pada pemadatan yang optimum memenuhi spesifikasi Bina Marga 2010.

\section{METODE PENELITIAN}

Dalam penelitian ini pengujian dilakukan secara bertahap, yang terdiri dari pengujian agregat (agregat kasar, agregat halus, dan filler), aspal, dan pengujian terhadap campuran yang terdiri dari Uji Marshall, Kepadatan Membal (Refusal Density), dan Stabilitas Sisa.

Untuk pengujian agregat terdiri dari pengujian berat jenis, pengujian berat isi, analisa ayak, pengujian kadar air, dan pengujian kadar lumpur. Adapun Pengujian aspal terdiri dari pengujian berat jenis, pengujian penetrasi, pengujian daktilitas, pengujian titik nyala, pengujian titik lembek. Metode yang digunakan untuk pengujian campuran adalah metode Marshall, dimana dari pengujian Marshall tersebut didapatkan hasil yang berupa stabilitas, flow, void in total mix (VITM), void filled with asphalt, dan kemudian didapatkan nilai Marshall Qu otient (MQ).

\section{Variabel Penelitian}

Variabel bebas dalam penelitian ini adalah variasi kadar aspal 5,0; 5,5;6,0;6,5;7\%, variasi Wetfix Be 0,0;0,2;0,3;0,4\% terhadap kadar aspal optimum dan variasi suhu pemadatan70, 90, 110, 130, 150 dan $160^{\circ} \mathrm{C}$. Adapun variabel terikat (parameter penelitian) terdiri dari stabilitas dan kelelehan meliputi : kepadatan, prosen rongga dalam agregat, prosen rongga dalam campuran, prosen rongga terisi aspal, kelelehan, stabilitas, Marshall Quotient.

\section{Lokasi dan Bahan-bahan Penelitian}

Penelitian ini dilakukan di laboratorium uji bahan jurusan Teknik Sipil Politeknik Negeri Jakarta. Adapun bahan-bahan yang digunakan dalam penelitian ini adalah aspal Esso, agregat kasar batu pecah, abu batu dan filler semen portland serta bahan anti Stripping Wetfix Be.

\section{HASIL DAN PEMBAHASAN}

\section{Hasil Pengujian Agregat dan Aspal}

Dari hasil pengujian sifat fisik agregat, baik untuk agregat halus maupun agregat kasar semuanya memenuhi Spesifikasi [8]. Hasil pemeriksaan sifat fisis agregat disajikan pada Tabel 1. Adapun Hasil Pemeriksaan Sifat Fisis Aspal dengan Wetfix-Be semuanya memenuhi Spesifikasi [8]. Hasil pemeriksaan sifat fisis agregat disajikan pada Tabel 2. 
Tabel 1. Hasil Pemeriksaan Sifat-sifat Fisis Agregat

\begin{tabular}{lllll}
\hline \multirow{2}{*}{ Pengujian } & \multirow{2}{*}{ Sat. } & $\begin{array}{l}\text { Hasil } \\
\text { Pengujian }\end{array}$ & \multicolumn{2}{c}{ Spesifikasi SNI 8198-2015 } \\
\cline { 5 - 5 } BJ Agregat Halus & & & & Max \\
-Bulk & & $\mathbf{2 . 5 3}$ & 2.5 & - \\
-SSD & & $\mathbf{2 . 5 9}$ & 2.5 & - \\
-Semu & & $\mathbf{2 . 7 1}$ & 2.5 & \\
Penyerapan Air & $\%$ & $\mathbf{2 . 6 7}$ & - & 3 \\
Kadar Lumpur & $\%$ & $\mathbf{5 . 5}$ & - & 10 \\
BJ Agregat Kasar & & & & \\
-Bulk & & $\mathbf{2 . 5 9}$ & 2.5 & - \\
-SSD & & $\mathbf{2 . 6 4}$ & 2.5 & - \\
-Semu & & $\mathbf{2 . 7 4}$ & 2.5 & \\
Penyerapan Air & $\%$ & $\mathbf{2 . 1 5}$ & - & 3 \\
Kadar Lumpur & $\%$ & $\mathbf{0 . 8 4}$ & - & 1 \\
\hline
\end{tabular}

Tabel 2. Hasil Pemeriksaan Sifat Fisis Aspal dengan Wetfix-Be

\begin{tabular}{lllll}
\hline \multirow{2}{*}{ Pengujian } & \multirow{2}{*}{ Sat. } & $\begin{array}{l}\text { Hasil } \\
\text { Pengujian }\end{array}$ & \multicolumn{2}{c}{ Spesifikasi SNI 8198-2015 } \\
\cline { 5 - 5 } & & & Min & Max \\
\hline Berat & & $\mathbf{1 . 0 2}$ & 1.0 & - \\
Jenis & & 60 & 60 & 79 \\
$\begin{array}{l}\text { Penetrasi } \\
\text { mm }\end{array}$ & $\mathbf{6 5}$ & & - \\
Titik & & & 48 & \\
Lembek & ${ }^{\circ} \mathrm{C}$ & $\mathbf{4 8 . 5 0}$ & 100 & - \\
Daktilitas & $\mathrm{cm}$ & $\mathbf{1 0 1 . 0 0}$ & 100 \\
\hline
\end{tabular}

\section{Hasil Pengujian Marshall}

Hasil pengujian Marshall untuk variasi suhu pemadatan pada KAO 6\%, dan Wetfix Be 0,3\% dari kadar aspal, rekapitulasi disajikan pada Tabel 3 dan Grafik 1a s/d 1h.

\section{a. Kepadatan}

Kepadatan (density) merupakan berat campuran yang dinyatakan dalam satuan volume. Kepadatan dipengaruhi oleh beberapa faktor antara lain gradasi campuran, jenis dan kualitas bahan susun, kadar aspal, kekentalan aspal, dan suhu pemadatan. Semakin tinggi suhu pemadatan, nilai kepadatan semakin meningkat. Hal ini disebabkan karena pada suhu pemadatan yang tinggi aspal lebih mudah masuk ke dalam campuran untuk menempati ruang-ruang kosong sehingga rnengakibatkan rongga dari pada campuran yang terisi aspal semakin meningkat. Nilai kepadatan yang dihasilkan pada suhu pemadatan $70^{\circ} \mathrm{C}$ sampai $160^{\circ} \mathrm{C}$ sebesar 2,10 - 2,26 $\mathrm{gr} / \mathrm{cm} 3$ (seperti pada Tabel 3 dan Gambar 1a).

b. Rongga diantara Agregat (VMA)

Void in mineral aggregate (VMA) atau rongga udara di antara butiran agregat adalah rongga udara dalam campuran beton aspal padat tanpa selimut aspal. Rongga udara di antara agregat akan meningkat jika agregat yang digunakan bergradasi terbuka. Hasil penelitian menunjukkan bahwa Nilai VMA semakin menurun dengan bertambahnya suhu pemadatan pada campuran beraspal, namun untuk nilai VMA pada suhu pemadatan $70^{\circ} \mathrm{C}$ sampai $160^{\circ} \mathrm{C}$, masih memenuhi syarat [7], minimal 15\% (seperti pada Tabel 3 dan Gambar 1b). 


\section{c. Rongga Terisi Aspal (VFB)}

Volume of voids filled with asphalt atau volume rongga udara beton aspal yang terisi aspal merupakan bagian dari VMA yang terisi oleh aspal, tidak termasuk di dalamnya aspal yang terabsorbsi oleh masing-masing butiran agregat. Dengan demikian aspal yang mengisi VFB adalah aspal yang berfungsi untuk menyelimuti butir-butir agregat di dalam beton aspal padat. Atau dengan kata lain VFB inilah yang merupakan persentase volume beton aspal padat yang menjadi selimut aspal. Nilai VFB meningkat dengan bertambahnya suhu pemadatan, dikarenakan rongga agregat pada campuran lebih banyak terisi aspal sehingga pori antar agregat semakin rapat. VFB pada suhu pemadatan $110^{\circ} \mathrm{C}$ sampai $160^{\circ} \mathrm{C}$, masih memenuhi syarat [7], minimal 65\%.(seperti pada Tabel 3 dan Gambar 1c.)

d. Rongga Dalam Campuran (VIM)

Void in the mix (VIM) atau rongga udara dalam campuran merupakan rongga udara yang masih tersisa setelah campuran beton aspal dipadatkan. Rongga udara dalam campuran yang terlalu besar akan mengakibatkan berkurangnya sifat kekedapan air, sehingga akan menurunkan sifat durabilitas atau keawetan beton aspal. Dan jika rongga udara terlalu kecil akan mengakibatkan beton aspal terjadi bleeding pada temperatur yang tinggi. Rongga udara dalam campuran yang cukup dibutuhkan untuk bergersernya butiran agregat akibat beban tambahan setelah pemadatan. Nilai VIM semakin menurun dengan bertambahnya suhu pemadatan, karena pada suhu pemadatan yang tinggi tingkat kepadatan yang dihasilkan juga lebih tinggi sehingga memperkecil rongga dalam campuran. Atau dengan kata lain nilai VIM yang semakin meningkat, pada suhu pemadatan rendah, aspal sulit menyelimuti agregat sehingga aspal dan agregat tidak dapat menyampur secara homogen VIM pada suhu pemadatan $120^{\circ} \mathrm{C}$ sampai $160^{\circ} \mathrm{C}$, masih memenuhi syarat Bina Marga 2010 , sebesar 3,5 - 5,5\% (seperti pada Tabel 3 dan Gambar 1d).

\section{e. Stabilitas}

Nilai stabilitas meningkat dengan bertambahnya suhu pemadatan mulai dari $70^{\circ} \mathrm{C}$ sampai $160^{\circ} \mathrm{C}$, hal ini disebabkan pada suhu yang lebih tinggi (sampai $160^{\circ} \mathrm{C}$ ), aspal akan lebih mudah mencair (konsistensi rendah) dan masuk di antara rongga agregat dengan lebih sempurna dan menjadikan pelumas untuk menempatkan agregat pada ruang yang kosong dan pada akhirnya akan menghasilkan nilai stabilitas yang lebih baik. Nilai stabilitas yang memenuhi persyaratan sesuai spesifikasi Bina Marga 2010 yaitu $>800 \mathrm{~kg}$ adalah stabilitas yang dihasilkan campuran pada pemadatan $90^{\circ} \mathrm{C}$ sampai $160^{\circ} \mathrm{C}$ dengan nilai stabilitas $900 \mathrm{~kg}-1500$ kg (seperti pada Tabel 3 dan Gambar 1e).

\section{f. Kelelehan}

Nilai Flow (kelelehan) menurun dengan bertambahnya suhu pemadatan mulai dari $70^{\circ} \mathrm{C}$ sampai $160^{\circ} \mathrm{C}$, hal ini dikarenakan semakin tingginya suhu pemadatan maka campuran beton aspal semakin padat dan mempunyai rongga-rongga yang lebih kecil sehingga pada saat dibebani kelenturannya kecil. Dari nilai flow yang masih memenuhi spesifikasi, maka perubahan bentuk (deformasi plastis) akibat pembebanan dapat terhindar dari keretakan. Nilai flow yang memenuhi persyaratan sesuai spesifikasi Bina Marga 2010 yaitu minimal $3 \mathrm{~mm}$ adalah pada pemadatan $70^{\circ} \mathrm{C}$ sampai $160^{\circ} \mathrm{C}$ dengan nilai stabilitas $4,02 \mathrm{~mm}-3,77 \mathrm{~mm}$ (seperti pada Tabel 3 dan Gambar 1f). 


\section{g. Marshall Quotient (MQ)}

Nilai Masrshall Quotient (MQ) atau hasil bagi Marshall meningkat dengan bertambahnya suhu pemadatan mulai dari $70^{\circ} \mathrm{C}$ sampai $160^{\circ} \mathrm{C}$. Nilai MQ yang memenuhi persyaratan sesuai spesifikasi Bina Marga 2010 yaitu minimal 250 $\mathrm{kg} / \mathrm{mm}$, adalah pada pemadatan $90^{\circ} \mathrm{C}$ sampai $160^{\circ} \mathrm{C}$ dengan nilai MQ $270-410$ $\mathrm{kg} / \mathrm{mm}$ (seperti pada Tabel 3 dan Gambar 1g). Pada Gambar 1h. berdasarkan spesifikasi serta hasil analisis, seluruh parameter Marshall yang memenuhi persyaratan terletak pada rentang suhu pemadatan $120^{\circ} \mathrm{C}$ sampai dengan $160^{\circ} \mathrm{C}$. Dari hasil tersebut dapat disimpulkan bahwa:

Tabel 3. Hasil Pemeriksaan Campuran Beton Aspal

\begin{tabular}{|c|c|c|c|c|c|c|c|c|}
\hline \multirow[t]{2}{*}{ Sifat Campuran } & \multirow{2}{*}{ Sat. } & \multicolumn{6}{|c|}{ Suhu Pemadatan $\left({ }^{0} \mathrm{C}\right)$} & \multirow{2}{*}{ Spec } \\
\hline & & 160 & 150 & 130 & 110 & 90 & 70 & \\
\hline Kepadatan & $\mathrm{gr} / \mathrm{cm}^{3}$ & 2.26 & 2.25 & 2.23 & 2.22 & 2.14 & 2.10 & - \\
\hline$\%$ Rongga diantara & $\%$ & 17.18 & 17.70 & 18.49 & 19.40 & 22.53 & 24.10 & Min 15 \\
\hline Agregat (VMA) & & & & & & & & \\
\hline $\begin{array}{l}\text { \% Rongga Terisi Aspal } \\
\text { (VVB) }\end{array}$ & $\%$ & 77.75 & 74.98 & 71.19 & 67.41 & 58.51 & 55.08 & Min 65 \\
\hline $\begin{array}{l}\text { \% Rongga Thd Camp } \\
\text { (VIM) }\end{array}$ & $\%$ & 3.82 & 4.43 & 5.32 & 6.29 & 9.05 & 10.82 & $3.5-5.5$ \\
\hline Stabilitas & $\mathrm{kg}$ & $\begin{array}{l}1908 . \\
87\end{array}$ & $\begin{array}{l}1001 . \\
83\end{array}$ & $\begin{array}{l}1454 . \\
72\end{array}$ & $\begin{array}{l}1265 . \\
32\end{array}$ & $\begin{array}{l}917.6 \\
8\end{array}$ & $\begin{array}{l}648.5 \\
1\end{array}$ & Min 800 \\
\hline Kelelehan & $\mathrm{mm}$ & 3.77 & 3.73 & 4.05 & 3.8 & 4.03 & 4.02 & Min 3 \\
\hline Marshall Quotient & $\mathrm{kg} / \mathrm{mm}$ & $\begin{array}{l}519.6 \\
1\end{array}$ & $\begin{array}{l}314.4 \\
6\end{array}$ & $\begin{array}{l}358.3 \\
9\end{array}$ & $\begin{array}{l}344.7 \\
5\end{array}$ & $\begin{array}{l}229.4 \\
2\end{array}$ & $\begin{array}{l}161.6 \\
8\end{array}$ & $\operatorname{Min} 250$ \\
\hline
\end{tabular}

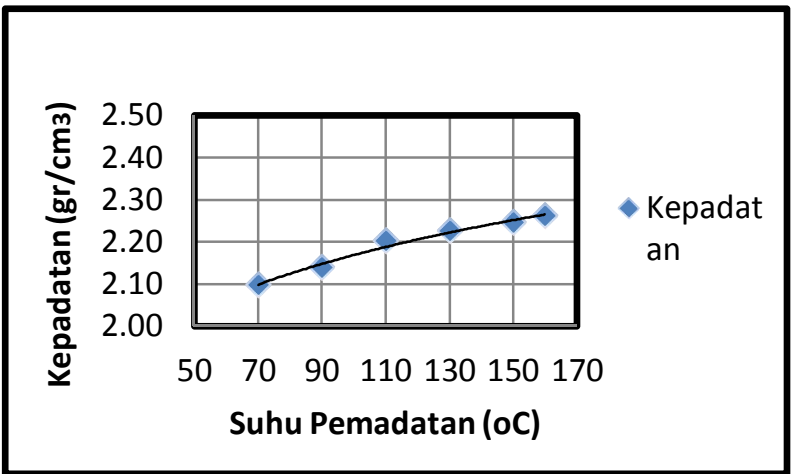

Gambar 1a. Grafik Kepadatan

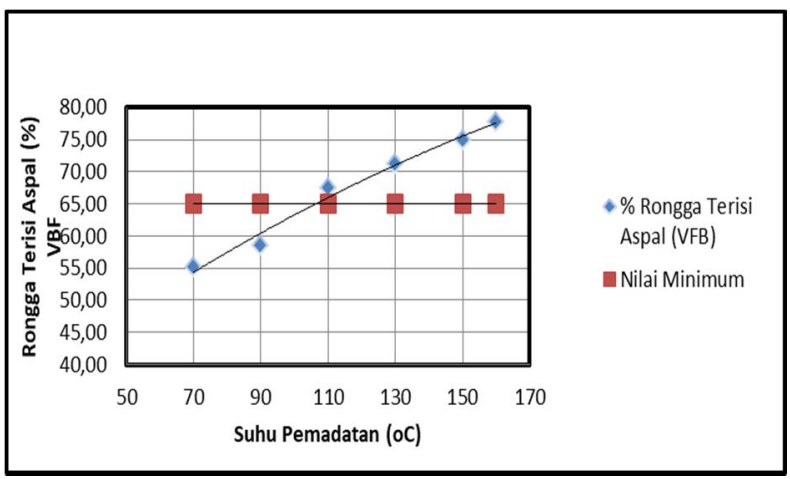

Gambar 1c. Grafik VFB

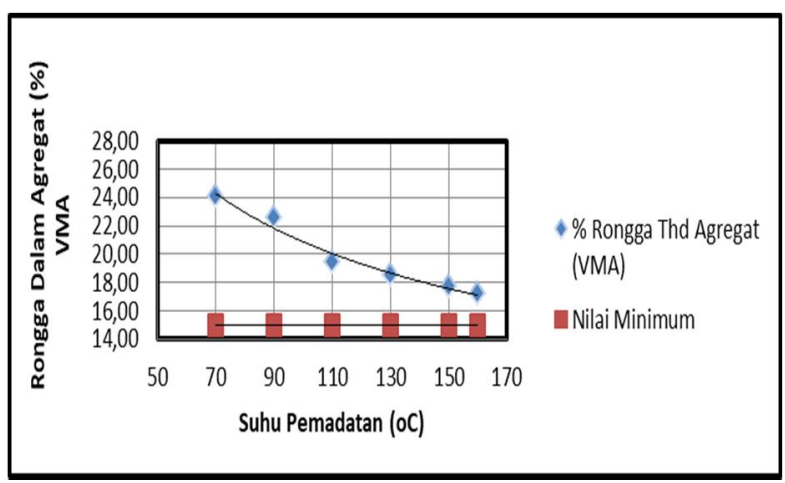

Gambar 1b. Grafik VMA

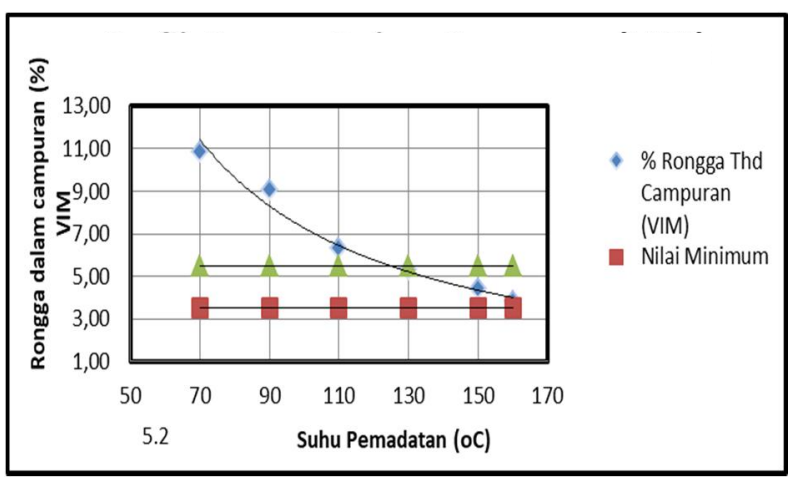

Gambar 1d. Grafik VIM 


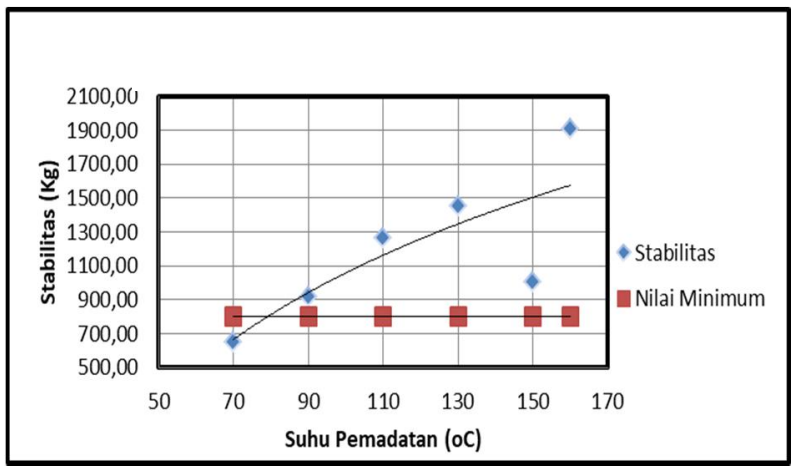

Gambar 1e. Grafik Stabilitas

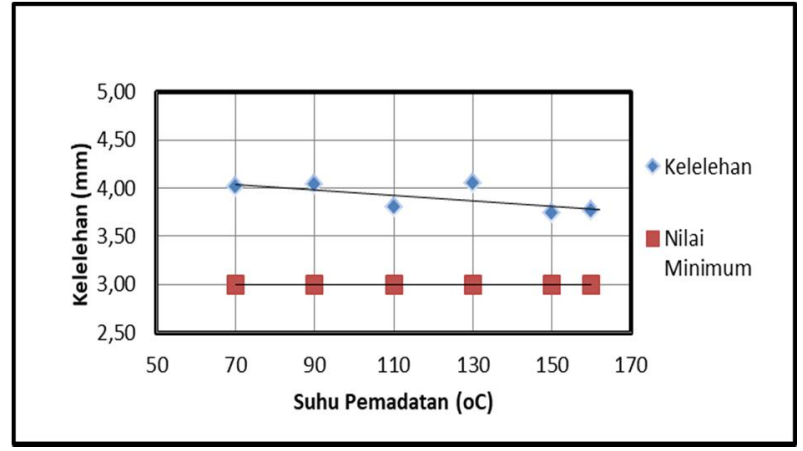

Gambar 1f. Grafik Kelelehan

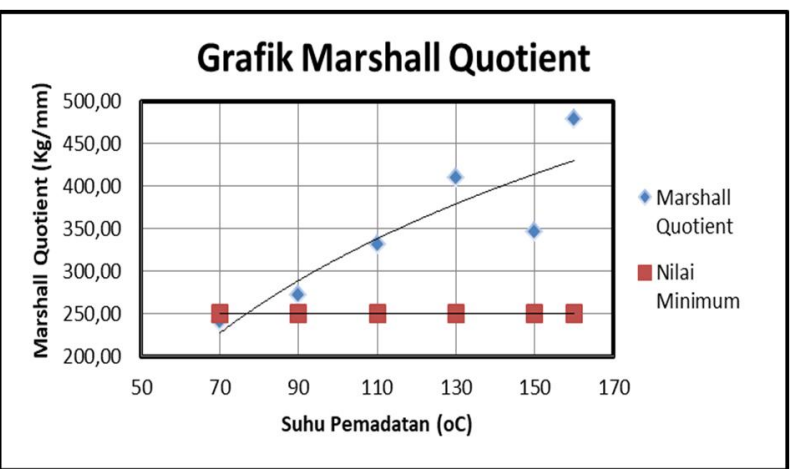

Gambar 1g. Grafik MQ

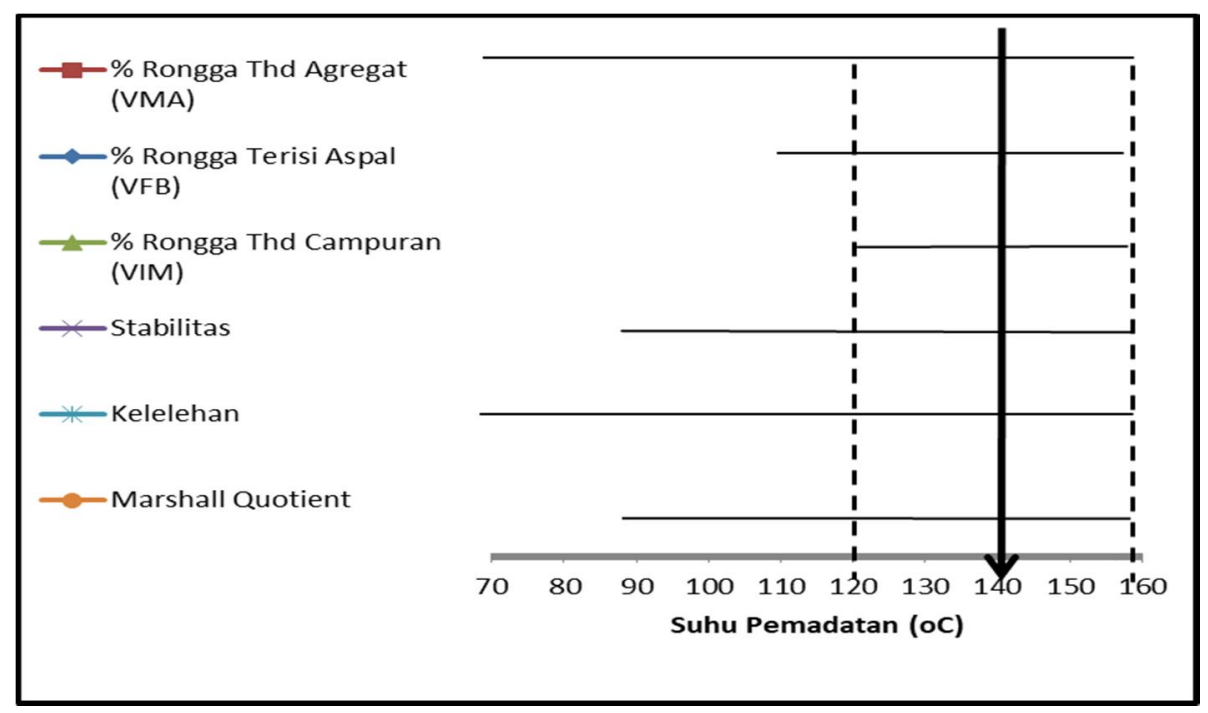

Gambar 1h. Bagan Penentuan Suhu Pemadatan Optimum

Suhu Pemadatan Optimum $=\left\{\left(120^{\circ} \mathrm{C}+160^{\circ} \mathrm{C}\right): 2\right\}=140^{\circ} \mathrm{C}$

Hasil Sifat Mekanis dengan menggunakan Suhu Pemadatan Optimum dapat dilihat pada Tabel 4. Pada suhu pemadatan $140^{\circ} \mathrm{C}$ semua parameter Marshall memenuhi spesifikasi [7]. 
Tabel 4. Hasil Sifat - Sifat Mekanis dengan Menggunakan Suhu Pemadatan Optimum

\begin{tabular}{|c|c|c|c|}
\hline Sifat Campuran & $\begin{array}{l}\text { Suhu } \\
\text { Pemadatan } \\
\text { Optimum } \\
140^{\circ} \mathrm{C}\end{array}$ & Spesifikasi & Keterangan \\
\hline Kepadatan $(\mathrm{gr} / \mathrm{cm} 3)$ & 2,24 & & \\
\hline \% Rongga Diantara Agregat (VMA) & 18.10 & $\min 15$ & Memenuhi \\
\hline \% Rongga Terisi Aspal (VFB) & 73.09 & $\min 65$ & Memenuhi \\
\hline \% Rongga Thd Campuran (VIM) & 4.88 & $3.5-5.5$ & Memenuhi \\
\hline Stabilitas $(\mathrm{kg})$ & 1228.28 & $\min 800$ & Memenuhi \\
\hline $\operatorname{Kelelehan}(\mathrm{mm})$ & 3.93 & $\min 3$ & Memenuhi \\
\hline Marshall Quotient (kg/mm) & 362.14 & $\min 250$ & Memenuhi \\
\hline
\end{tabular}

\section{KESIMPULAN}

Berdasarkan analisis hasil penelitian, dengan KAO 6\%, kadar Wetfix Be 0,3\%, dan variasi suhu pemadatan $70,90,110,130,150$ dan $160^{\circ} \mathrm{C}$, penambahan suhu pemadatan pada aspal beton dapat meningkatkan nilai kepadatan, \% Rongga Terisi Aspal, Stabilitas, dan Marshall Quotient serta menurunkan \% rongga di antara agregat, \% rongga dalam campuran dan kelelehan. Rentang Suhu pemadatan yang masih memenuhi parameter Marshall yaitu pada suhu $120^{\circ} \mathrm{C}$ sampai dengan $160^{\circ} \mathrm{C}$. Adapun nilai suhu optimum pemadatan untuk campuran beton aspal yang sebesar $140^{\circ} \mathrm{C}$, dengan nilai VMA 18,10\%, VFB 73,09\%, VIM 4,88 \%, Stabilitas 1228,28 kg, kelelehan 3,93 mm dan MQ 362,14 kg/mm, memenuhi spesifikasi Bina Marga 2010

\section{UCAPAN TERIMAKASIH}

Dalam kesempatan ini penulis banyak mengucapkan terimakasih yang sedalamdalamnya kepada semua pihak yang telah membantu penelitian ini terutama kepada Kepala PPPM Politeknik Negeri Jakarta, yang telah menyalurkan dana dari DIPA Politeknik Negeri Jakarta dan Kusno, alumni Jurusan Teknik Sipil yang sudah membantu pada proses pelaksanaan dan pengambilan data di laboratorium.

\section{DAFTAR PUSTAKA}

[1] Susilowati, Anni dan Wiyono, Eko (2015), Penggunaan Bahan Anti Stripping untuk Campuran Beton Aspal, Jurnal Poli-Teknologi, ISSN 1412-2782/eISSN 2407-9103, Volume 16 No 1 Januari 2017.

[2] Sukirman, Silvia. 2012. Beton Aspal Campuran Panas. Edisi kedua, cetakan ketiga. Bandung: Institut Teknologi Nasional.

[3] Aschuri, Imam, Rahman, RP. 2008. Kajian Suhu Optimum Pada Proses Pemadatan Untuk Campuran Beraspal Dengan Menggunakan Modifikasi Bitumen Limbah Plastik, Makalah Proceeding International Conference On Geotechnical \& Highway Engineering, Geotropika 2008, Malaysia, 26-27 May 2008, Upload by Asep Kamaludin - April 12, 2013

[4] Adibroto, F., 2003, Penentuan Temperatur Pencampuran dan Pemadatan Campuran Beraspal, Penerbit Granit, Jakarta 
[5] Syarwan, 2012, Kajian Variasi Suhu Pemadatan Pada Beton Aspal Menggunakan Aspal Retona Blend 55, Jurnal Portal, ISSN 2085-7454, Volume 4 No. 1, April 2012.

[6] Raharjo, Budi Pratomo, Priyo, Ali Hadi. 2016. Pengaruh Suhu Pemadatan Campuran Untuk Perkerasan Lapis Antara (AC-BC), JRSDD, Edisi Maret 2016, Vol. 4, No. 1, Hal:43 - 50 (ISSN:2303-0011).

[7] Spesifikasi Umum Bina Marga Divisi 6, 2010, Perkerasan Aspal, Direktorat Jendral Bina Marga.

[8] SNI-8198-2015, Spesifikasi Campuran Beraspal Panas Bergradasi Menerus (Laston), Badan Standarisasi Nasional 